\title{
A Dictionary of South African English on Historical Principles:" A Case of Lexical Invasion or Corpus Enhancement?
}

Liesel Hibbert, Department of English, University of the Western Cape, Bellville, South Africa

\begin{abstract}
The DSAE (A Dictionary of South African English on Historical Principles) embraces linguistic diversity by including many Afrikaans lexemes and lexemes from African languages. In the advertising pamphlet the dictionary proposes to, among other things, improve communication, give access to education, change perceptions of SAfE (South African English) locally and internationally, improve historical and political perspectives and create a new South African identity. These statements are discussed in relation to popular local debates around "standards", language variation and policy. An overview is given of the current status of SAfE in the context of Southern Africa and Africa. Finally I argue in favour of the dictionary as documentary evidence of a living spoken language at a given point in history.
\end{abstract}

Keywords: DICTIONARY, LEXICOGRAPHY, SOUTH AFRICAN ENGLISH, VARIETIES OF ENGLISH, INTERCULTURAL COMMUNICATION, MULTILINGUALISM, SOUTH AFRICAN IDENTITY, LANGUAGE PLANNING, DISCOURSE COMMUNITIES, ORGANIZATION OF AFRICAN UNITY, COLLOQUIALISMS, REGIONALISMS, LANGUAGE SHIFT, LANGUAGE CHANGE, DIALECT, LOAN-WORDS, BORROWINGS, AFRICANISMS, AFRIKAANSISMS, BLACK SOUTH AFRICAN ENGLISH, LINGUISTIC CHARTER FOR AFRICA, STANDARDIZATION, CORPUS ENHANCEMENT, LEXICAL INVASION, SOCIOLINGUISTICS

\section{Opsomming: A Dictionary of South African English: 'n geval van leksikale} indringing of korpusuitbreiding? Die DSAE ( $A$ Dictionary of South African English on Historical Principles) omvat taalverskeidenheid deur baie Afrikaanse lekseme en lekseme uit Afrikatale in te sluit. Die woordeboek onderneem in die advertensiepamflet om onder andere kommunikasie te verbeter, toegang tot onderrig te verleen, persepsies oor SAfE (Suid-Afrikaanse Engels) binnelands en internasionaal te verander, historiese en politieke perspektiewe te verbeter en 'n nuwe Suid-Afrikaanse identiteit te skep. Hierdie stellings word met verwysing na populêre plaaslike debatte oor "standaarde", taalvariasie en beleid bespreek. ' $n$ Oorsig word gegee van die huidige status van SAfE binne die konteks van Suider-Afrika en Afrika. Ten slotte lewer ek 'n betoog ten gunste van die woordeboek as dokumentêre bewys van 'n lewende gesproke taal op ' $n$ bepaalde oomblik in die geskiedenis.

Silva, Penny (Managing Ed.). 1996. A Dictionary of South African English on Historical Principles. Cape Town: Oxford University Press. 
Sleutelwoorde: WOORDEBOEK, LEKSIKOGRAFIE, SUID-AFRIKAANSE ENGELS, VARIËTEITE VAN ENGELS, INTERKULTURELE KOMMUNIKASIE, VEELTALIGHEID, SUIDAFRIKAANSE IDENTTTEIT, TAALBEPLANNING, SPRAAKGEMEENSKAPPE, ORGANISASIE VIR AFRIKA-EENHEID, SPREEKTAALUITDRUKKINGS, STREEKTAALUITDRUKKINGS, TAALVERSKUIWING, TAALVERANDERING, DLALEK, LEENWOORDE, ONTLENINGS, AFRIKANISMES, AFRIKAANSISMES, SWART SUID-AFRIKAANSE ENGELS, TAALMANIFES VIR AFRIKA, STANDAARDISERING, KORPUSUITBREIDING, LEKSIKALE INDRINGING, SOSIOLINGUISTIEK

\section{Introduction}

The DSAE (Dictionary of South African English on Historical Principles) is an open invitation to all South Africans to come out of their linguistic laagers. The dictionary cuts through common discourse systems and presents us with what has so often been termed "levelling the playing fields". Voluntary and involuntary discourse systems are laid bare, stripped of stigma or elevated status, and are listed alongside each other.

But is this desirable? Do we regard our dialects as acceptable? Is local really lekker? Not everyone would agree. The DSAE which appeared in September 1996 challenges many notions of what may be regarded as standard English in South Africa today. Surveying the responses that have already appeared, we find that some are outraged and others charmed and delighted by the appearance of the dictionary. A selection of titles of the reviews reveal a wide range of attitudes, e.g. "Lapping up our lekker lexicon" (Bundy 1996: 1-2) "Dictionary has cultural bias" (Landau 1996: 16) and "Dictionary deserves a good word" (Hughes 1996: 23). What most readers seem to react to in their different ways is the vast extent to which loan-words, borrowings, dialectical lexemes, regionalisms and colloquialisms are recorded and painstakingly glossed. Issues which the dictionary raises for linguists are questions regarding lexical invasion of core vocabularies vs corpus extension and enhancement, condoning diversity vs maintaining "standards" and the maintenance vs blurring of distinctions between first- and second-language Englishes, a distinction which has been heavily entrenched in the South African education systems.

A very general question which would suitably frame this discussion would be: Does the DSAE do what it is designed to? In the glossy four-page advertising pamphlet distributed by Oxford University Press, it is stated that the dictionary "extends far beyond the field of South African language studies" and that it contributes towards improved communication, education, historical understanding, political perspective, the development of the arts, a South African identity, changing the local perception of South African English and international lexicography. Each of these is qualified in a brief paragraph. Most of my discussion will be centered around those assertions.

The advertisement claims that: "With English becoming an increasingly important lingua franca in South Africa it is essential that people have tools like 
the DSAE to help them use and understand the language." It is also stated that the dictionary is "certain to be found and frequently consulted in educational and public libraries". The assertion that the dictionary will be widely consulted by secondary and tertiary students and by the public is based on the assumption of consensus about the centrality of English among the population at large. There is also the assumption that everyone wants to overcome communication barriers and embrace linguistic diversity and to see the DSAE as the answer to a common national goal. In response to this one may ask whether, as more and more African language speakers move into high status educational-, politicaland business-related contexts, the lingua franca in these contexts will remain English. Numerous linguists and sociologists have developed strong arguments to the contrary, i.e. Heugh (1996: 17) and Prah (1995: 15). All these writers dispute the notion that English is the "natural" African or Pan-African lingua franca. They also reject a number of current assumptions about intercultural communication, i.e. that English is dominant internationally, that English is the language of international trade and future African trade and that intercultural competence is synonymous with fluency in English. But if we accept for the sake of argument that English has or will have the dominant status claimed for it, the appearance of the DSAE has foregrounded the question of which variety of English is to perform this national and international function. To answer this question, a closer look at the current status of different Englishes in Southern Africa is needed.

\section{The Current Status of Englishes in Southern Africa - An Overview}

Southern African Englishes are currently categorized according to the sociopolitical order constructed under apartheid rule. In order to recognize diversity in the reconstruction of society, the labels and hierarchies put in place to elevate some dialects and varieties above others, I believe, need to be re-evaluated. Over and above that, colonialism has entrenched the notion of English as the chief source of knowledge which was already a commonsensical notion at the turn of the century, almost 100 years ago:

Probably everyone would agree that an Englishman would be right in considering his way of looking at the world and at life better than that of the Maori or Hottentot, and no-one will object in the abstract to England doing her best to impose her better and higher view on these savages ... Can there be any doubt that the white man must, and will, impose his superior civilization on the coloured races? (Earl Grey 1899, quoted in Hodson 1902: 158 and cited in Skuttnabb-Kangas and Phillipson 1994: 336-337)

Has anything changed since then? Where do South African linguists in the 1990s stand in relation to this view? Titlestad (1996: 169) maintains: 
A notably different SAfE (South African English) would merely mean that two varieties of English would have to be taught and learned. The damage, once done, would be difficult to undo, and South Africa would have lost one of its vital resources, its chief source of knowledge.

Titlestad seems to subscribe to the notion of two clear varieties of English, the first- vs second-language variety. What is also clear is that he is in favour of the $\mathrm{L} 1$ variety for educational purposes. In contrast to this, the $D S A E$ unquestionably blurs the distinction between these two varieties.

According to Lanham and MacDonald (1979) there are four common current labels used to refer to SAfE (South African English). All of them are problematic in today's situation.

Significant sociolinguistic shifts since 1992 have been brought about by the removal of the Group Areas Act, the removal of the homeland policy, constitutionally enshrined multilingualism (11 official languages), mobility of the previously disenfranchised sector of the population into Model C schools (previously "White schools"), increased access to tertiary education and the lifting of the international cultural and economic boycotts bringing about, in addition to links with other continents, new links with the rest of sub-Saharan Africa and Africa as a whole.

The first of these labels is "conservative SAfE". The implication of this label is that it links accent and political affiliation thereby oversimplifying sociolinguistic realities, resulting in inaccuracies in grouping of speakers. Secondly, "acceptable" SAfE implies that the accent is too broad to be regarded as "standard English". Thirdly, "extreme" SAfE implies that it is not "proper" English at all. Fourthly, Black South African English (BSAfE) as it is referred to by Gough (1996) and Buthelezi (1995) could imply that all black South Africans (which would constitute the vast majority of the population) all speak the same English.

The sociolinguistic shifts and discourses on language planning in Africa in the current literature on Pan-African language policy, suggest two necessary shifts in point of view on English in South Africa. Firstly, a shift from references to ethnically defined speech communities to Pan-Southem African speech communities with many overlaps, taking into account social shifts. Secondly, a shift from references to colour as the only variable to consideration of multiple variables or combinations of variables such as, for instance, regionality, socioeconomic status of educational institutions and levels of income. The necessary paradigm shift would constitute not viewing SAfEs in terms of British English (measured against current British standards) to viewing it in relation to other African Englishes in sub-Saharan Africa, and defining it as a modern African language. Another good reason for looking at English in Africa differently would be to fall in line with the Linguistic Charter for Africa. In terms of the Charter, according to Dalby 1985: 29 cited in Skuttnabb-Kangas and Phillipson (1994: 344-345), it is proposed: 
That the equal linguistic rights of every individual be recognised, together with the need to provide access to literacy in every living African language.

That as many languages as possible in each African state, depending on the number of speakers, be given the status of national languages, with an established place in the national education system and in the media.

That at least one African language in each state be given the status of official language, to replace or be used alongside any existing "foreign" official language.

What parallels can be drawn between the manifesto above and the emergence of a high-status variety of African English in South Africa as reflected in the DSAE? According to some (e.g. Gough 1996 and Buthelezi 1995) "Black English" as it is commonly referred to in the current literature on South African sociolinguistics published post-1992, has already emerged, according to others it will still emerge. This raises questions about the spread and ownership of this variety of English as well as the label. The label "Black English" raises two fundamental issues: the labelling of speech communities on ethnic lines, and the notion that South Africa is on its way to becoming a melting-pot. Apartheid has caused speech communities to be conceived of as separate and distinct, but this can no longer hold. As is pointed out by De Klerk (1996: 9), the label "Black English" has two connotations: one, of subscribing to the American melting-pot philosophy, which I think is too simplistic a view given our very multilingual population and two, of separating speech communities along ethnic lines, which she too points out, is no longer regarded as "politically correct".

Due to the high degree of language contact between English, Afrikaans and African language speakers over a great number of decades, it is often difficult to distinguish between English, Afrikaans and African language origins, as in the case of the following two entries, jol and kwela. Jol is a word so commonly used in South Africa that it hardly needs an explanation, yet the origins of the word remain reasonably obscure. It is said that the pronunciation of the word is either derived from Afrikaans or is an English pronunciation of the Afrikaans word. Here one might speculate whether the word was perhaps derived from the Afrikaans word jolyt or from the English word jolly. This demonstrates how intermingled the two languages are historically.

Kwela is said to have its origins in Xhosa and Zulu from the word khwela which means "climb on or in, to mount". The word has now taken on a variety of different connotations. Three different but related meanings are listed. Kwela is said to be a popular music style characterized by repetitive penny-whistle sounds, or kwela is the penny-whistle itself, or it is a dance-style which emerged around the late 1950s and early 1960s in the black ghettos around large African cities such as Johannesburg. Kwela-kwela is also listed and refers firstly to police vans and secondly to taxis. Again, there probably aren't that many South Africans who haven't heard the word before. 


\section{Facilitating Better Communications?}

Is this dictionary really going to add to the empowerment of local users as it proposes to? If it is, then one would be able to say that the editors are making a positive contribution to corpus enhancement. The phrase "lexical enhancement" would be inappropriate, as the word invasion implies that unwanted neologisms which muddy the so-called "purity" of the language are imposed, even forced on users, and which have negative effects on its users. The stance against "lexical invasion" has clearly been a very powerful one in the past and it seems, is being deliberately opposed by the editors.

The advertising pamphlet reminds us that: "The language includes both formal and colloquial words, which are indispensable to the proper understanding of fields as diverse as politics, the arts, flora and fauna ... Terms such as influx control, Africanism, indaba ... enable the environment to be fluently and accurately described." My point here is that focusing on fluency and accuracy glosses over social class in relation to variety spoken in different contexts. It would be true to say that the dictionary facilitates enhanced communication and access to education if it lends any guidance at all on desirability of specific lexical items in specific discourse contexts. This is, however, not the case. The dictionary tries to be as unprescriptive as possible. Therefore, one assumes, the listings for each lexeme do not include field labels (indicating certain disciplines or areas of knowledge in which the words might appear) status labels or usage labels (indications of where and when the words might be appropriate), or geographic labels and temporal labels.

The DSAE attempts to destigmatize South African varieties of English which, even in the international sphere, have elicited much-documented ridicule. D. Chrysal (1995: 357) caricatures South African English as spoken by white South Africans. He ridicules the pronunciation as a patois-type, uneducated, crude version of "standard" English, in an attempt, it seems, to appear politically correct. To enhance his point of view his text is accompanied by a visual of a naively laughing fresh-faced, wide-eyed male and supposedly signifying Dutch origin accompanied by the text "AH BIG YAWS?" (which is supposed to mean "pardon" or "I beg your pardon"). His treatment of South African English is superficial, generalized and therefore insensitive to the local user spectrum, especially as it disregards entirely the English spoken by the majority of South Africans who do not fall into the category he chooses to pick on.

The series Varieties of English around the World edited by Manfred Gorlach, a collection of papers incorporating sociolinguistic descriptions of Englishes around the globe, represents the way in which language dictionaries, lexicons and ways of thinking about standard written forms is seen to have taken on a descriptive rather than prescriptive function. Parakrama (1995) on the dehegemonizing of English also seems to subscribe to the trend towards descriptivism in sociolinguistics. 
In the advertising pamphlet, the importance of the $D S A E$ to international lexicography is said to be the following:

South African English is considered an important variety and has given the English-speaking world such words as apartheid and trek. While there are systematic and comprehensive dictionaries of the English used in, for example, the USA, Canada and Australia, there is no such work on South African English. The DSAE will fill this gap in the lexicography of English as a world language, and will be recognized and used as an authoritative source.

This assertion raises the issue of authority of sources. Cameron (1995: 50) explains how Oxford University Press publications are regarded as Coke (the real thing) while any others may be regarded as Pepsi (not quite the real thing). While Oxford University Press is certainly regarded in South Africa too as an authoritative source of legitimate knowledge, it needs to be acknowledged that much of the information in for instance the DSAE has been drawn from previous reliable and substantial sources. Two of these were also published by Oxford. They are D.R. Beeten and H. Dorner (1975) A Dictionary of English Usage in Southern Africa and J. and B. Branford (1991) A Dictionary of South African English. The DSAE, though, has made the previously collated material more readily accessible while furthering the project of recording language in use, which in addition assists people in studying the evolution of a living spoken language. This once again reflects the author's feeling that the language is being enhanced and extended in a positive way rather than "invaded".

\section{Contributing to Historical Understandings and Political Perspectives and a New South African Identity?}

It is stated in the advertising pamphlet that by systematically recording the changing use of words from the late 1500 s to the present and the changing ideas which they represent, the dictionary will make a significant contribution to the understanding of South African history and of political terms and concepts. Varying views have been expressed about the usefulness of recording historical origins and understandings of local lexemes in this dictionary.

Peter Wilhelm (1996: 22) is quoted as having written off the 25 years of dictionary compilation conducted by the Rhodes University Dictionary Unit as a "pointless exercise". His major objection is that the dictionary "puts all our linguistic scars on display". By this one assumed he is alluding to the sociopolitical atrocities of our national history which have brought into being a language which now provides blatant irreversible evidence of an embarrassing heritage. It may be said that Wilhelm suffers from an "ostrich mentality" (the tendency of denying evidence, as listed in the $O E D^{19}$ as ostrich behaviour: "the 
ostrich habit of burying their head in the face of everything they don't like"). Wilhelm is not going to be willingly politically repositioned in order to face his own heritage in a local language.

A related confusion is expressed by Julia Landau (1996: 16) who has pointed out that the dictionary suffers from a cultural bias and that the lexemes have been recorded from a colonial perspective which becomes apparent in definitions such as "bushman-a small nation of savage people ... low in stature, tawny colour'd with crisped hair", recorded in 1968 . The point which this reviewer misses, is that the DSAE is not pretending to be anything other than a reflection and record of our colonial history, if one believes that what language does is tell one's history.

A different stance is taken by Geoffrey Hughes (1996: 23). He insists that the origins of phrases and words "are important pieces of evidence in our complex, cruel and rich society history". This would be in line with the Foucauldian view that in democratizing institutionalized forms of voluntary and involuntary discourse, we need to focus on the historical conditions of the context and on the rules inherent in the formulation of such discourses.

The review of Colin Bundy (1996: 1-2) strikes a similar, more politically responsible note. He states that: "The complex and often brutal social history of the countryside is also represented by its specialist vocabulary." In his review, conducted from the perspective of a social historian with specific interests in land, its ownership, use and inhabitants, he does a word search through these themes and discovers much interesting background information, some missing lexemes, identifies some omissions and discrepancies, but is generally approving of the dictionary which he maintains "will delight and intrigue anyone interested in the language they speak and read and hear. It rewards serendipity and systematic inquiry with even-handed largesse."

This suggests that the DSAE may be able to act as a touchstone of perspectives on current cultural life in South Africa, or provide a new context to frame fractured societies and disruptive existences by simply legitimatising diversity. But rather than fostering a South African identity, should the dictionary not rather foster a Southern African identity? Does the relaxation of political boundaries between states in South Africa and in the Southern Africa region not render the label South African English as too limiting? Should one not rather speak of A Dictionary of Southern African English? Evidence has shown that African speakers of English have more commonalities than differences in the way in which Africanisms are incorporated into the English language. The present distribution of Southern Bantu languages, according to Herbert (1990), shows Nguni (which is Zulu and Xhosa) and the Sotho languages (Northern and Southern Sotho and Tswana) to be dominant in the Southern African region. This means that these two language groups are likely to have the heaviest impact on the English emerging in the Southern African region as a whole. South Africa's neighbours have, however, had more standard dialect in their school systems over a number of decades and therefore do not suffer from the 
interlanguage fossilization problem as much as South Africans do. In compiling a dictionary of Southern African English such as the DSAE, it might have been useful to conduct a comparative study of a specific list of lexical items and their origins and current meanings in Zimbabwe, Botswana and perhaps Namibia.

Can the DSAE really contribute to the development of local art-forms and literatures, as it is said to be able to? Performing arts and literature may be directly influenced. Writers of new South African multicultural texts which have become so popular, will probably have to subscribe to the definitions of the local works as prescribed. This raises a very important issue in regard to dictionary compilation. If lexical items for inclusion in this dictionary were last recorded in 1991, then what about the meanings of those words as they stand now in 1997? Significant political changes have resulted in substantial policy changes in, for instance, the media. The SABC is producing more locally flavoured advertisements and more local soap operas in an attempt to affirm and cater for African viewers and appealing to local music fans. Accent and pronunciation seem to have become a non-issue in the media. The scale seems to have been tipped from a high degree of correlation with British standard English to the "anything goes" zone in the last few years.

Let us look, for instance, at the well-known phrase yebo gogo. There has been much debate around the meaning of yebo gogo since it appeared in the Vodacom advertisement on national television three years ago. Everyone has a different definition for it. Now, to my surprise, I see that yebo and gogo are listed in the DSAE as English words.

In order to get a sense of what the current popular definition of the expression is, I conducted a survey with a group of 150 first-year English students at the University of the Western Cape. To the question, what does yebo mean and where does it come from, the most common responses were that it means "to agree with something" or "to admit something", that the meaning is "yes" or that it is a greeting. The most interesting response I got, was from one student who wrote: "It means 'hallo' or 'yes'. It has its origin in the AngloAfrican fusion of yes and bona. $S$ and na was dumped to give yebo." Most students said that gogo meant "grandmother". Some said it came from Zulu, some it came from Xhosa.

To the question, what does yebo gogo mean and where does it come from, most students wrote that it means "yes grandmother" and it comes from Zulu. Some said that it means that you are agreeing with your grandmother.

The DSAE explains yebo as being a term of approval, agreement or consent, i.e. in English "We say yes to ..." and is said to be pronounced as "yeh baw". According to the $D S A E, g \circ g \circ$ is a term of respect for an elderly person and is also used as title. An alternative meaning of gogo is "prophet" or "seer".

Is this corpus enhancement or lexical invasion? If yebo gogo is known and commonly used throughout South Africa, this must be an incident of corpus enhancement. The expression crosses all age, racial, ethnic and status barriers. 
However in this edition yebo and gogo are listed separately, while in the next edition they will have to be listed as one, because that has become the popular use of the expression since the appearance of the television advertisement for Vodacom through which it bacame popularized. The social and cultural tapestry in South Africa is rapidly being transformed by media policy and this in turn impacts on language change.

\section{Conclusion}

The DSAE subscribes to what may be termed "the variation ideology" (Neustupny 1993 quoted in Cameron 1995: 28) which "valorizes linguistic (and ethnic) diversity as a social good in itself" (Cameron 1995: 28), and condones the accommodation of diversity because it is said to enable minority participation in public discourse. It favours innovation over conservatism. In referring to the $D S A E$, one therefore cannot speak of "lexical invasion" as such, because many of the loanwords, borrowings, neologisms and innovations have existed in a very wide user system in the past, but have never before been acknowledged, recognized and accepted in any significant official way or by means of any official language-related policies in South Africa.

In the light of this, the DSAE does not make the task of educators any easier or the responsibility of language education any lighter. On the contrary, it amplifies the conflict between two fundamental concepts of linguistic democracy, one being that linguistic varieties should be encouraged, and the other that every individual in society has a right to access fluent Standard English and that it is the duty of the schools not to withhold this right. If linguists, educationalists and policy-makers resolve to work within the Organization of African Unity Language Plan for Action for Africa, this might entail subscribing to a resolution such as the one taken at the PRAESA (Project for Alternative Education in South Africa) Conference in July 1996 at the University of Cape Town. At this international seminar on language and education on the African continent, the resolution taken reads as follows:

Our promotion of L1 education goes hand-in-hand with our understanding that the people of Africa should be multilingual citizens in multilingual societies. For this reason, we believe that learners should be encouraged to acquire other relevant languages including languages of international communication and vehicular languages of cross-border, intra-African communication.

This is meant to imply that education and access to institutions, general language ability would be assessed, rather than proficiency in L1, L2, L3 or proficiency in medium of instruction. Would intercultural or cross-cultural competence be a factor? And, what is meant by intercultural competence? Would it mean understanding dialects, metaphors etc. of other varieties of English, or 
subscribing to a list of nuclear lexemes which are applicable internationally? The dictionary's existence puts the notion of a "nuclear vocabulary" into question. It seems to acknowledge that the boundaries between languages and language varieties are always blurred and that SAfE is a "moving target" as Bundy calls it in his review.

This dictionary, though painstakingly researched and compiled by a team of highly specialized linguists, serves to reduce the "user vs observer" paradox (Stubbs 1986: 71, from Labov 1972: "We would like ideally to observe how languages is used, when no one is observing it.") While this is not possible, the dictionary does blur traditional notions of distinctions between description and prescription and does not pretend to be a style-guide for appropriate usage. This might seem like an "anything goes" philosophy, but while a society is engaged in large-scale socio-political transformation, a context-appropriate style guide would probably be a bit premature.

This dictionary is potentially a first in line of a multitude of different South African English dictionaries still to come (as planned by the Dictionary Unit, Rhodes University). There will eventually be regional dictionaries, school dictionaries, academic dictionaries, historical dictionaries, geographical, cultural, musical, literary dictionaries and dictionaries such as the edition of a dictionary of political terminology published by the Mail and Guardian. Another useful publication would be a cross-cultural, cross-lingual, cross-regional reference thesaurus. This would be used in contexts of intercultural communication such as interpretation procedures in court and for worker vs management negotiations where it is crucial to accurately interpret meanings from nonstandard dialects.

By producing the DSAE, Oxford University Press has finally and officially severed the cross-continental umbilical chord with the "mother language" and has put SAfE decisively on the international linguistic map. So, is the DSAE a dictionary of slang? Aikona! Is it a must for every shelf? Yebo gogo! It's lank cool.

\section{References}

Beeton, D.R. and H. Domer. 1975. A Dictionary of English Usage in Southern Africa. Cape Town: Oxford University Press.

Branford, J. and B. Branford. 1991. A Dictionary of South African English. Cape Town: Oxford University Press.

Bundy, Colin. 1996. Lapping Up our Lekker Lexicon. Mail and Guardian Review of Books, Johannesburg, October 1996: 1-2.

Buthelezi, Q. 1995. South African Black English: Lexical and Syntactic Characteristics. Mesthrie, R. (Ed.). 1995: 242-250.

Cameron, D. 1995. Verbal Hygiene. London / New York: Routledge.

Chrystal, D. 1995. The Cambridge Encyclopedia of the English Language. Cambridge: Cambridge University Press. 
Dalby, D. 1985. The Life and Vitality of African Languages: A Charter for the Future. Mateene, Kahombo, John Kalema and Bernard Chomba (Eds.). 1985: 29-34.

De Klerk, Vivian. (Ed.). 1996. Focus on South Africa. Amsterdam: John Benjamins.

Gough, D. 1996. Black English in South Africa. De Klerk, Vivian (Ed.). 1996: 53-78.

Herbert, Robert K. 1990. The Sociohistory of Clicks in Southern Bantu. Anthropological Linguistics 32(3-4): 295-315, Fall and Winter.

Heugh, K. 1996. English Fiction. Bua! 10(2): 17-19, 33, August 1996.

Hughes, Geoffrey. 1996. Dictionary Deserves a Good Word. Sunday Times, 15 September 1996: 23.

Hodson, J.A. 1902. Imperialism, a Study. London: Allen and Unwin.

Labov, W. 1972. Some Principles of Linguistic Methodology. Language in Saciety 1: 97-120.

Landau, Julia. 1996. Dictionary has Cultural Bias. Cape Times, 13 September 1996: 16.

Lanham, L.W. and C.A. MacDonald. 1979. The Standard in South African English and its Social History. Heidelberg: Julius Gross.

Mateene, Kahombo, John Kalema and Bemard Chomba (Eds.). 1985. Linguistic Liberation and Unity of Africa. OAU/BIL Publication 6. Kampala: OAU Inter-African Bureau of Languages.

Mesthrie, R. (Ed.). 1995. Language and Social History: Studies in South African Sociolinguistics. Cape Town: David Philip.

Neustupny, J.V. 1993. History of Language Planning: Retrospect and Future Prospects. Keynote address to the tenth AILA World Congress, Amsterdam, 13 August.

Oxford University Press. Advertising pamphlet. A Dictionary of South African English on Historical Principles.

Parakrama, A. 1995. De-hegemonizing Language Standards: Leaming from Post-Colonial Englishes about English. London: Macmillan.

Prah, Kwesi. 1995. Foreign Languages "Hold Back Africa's Genius". Reported by Mxolisi Mgxashe. Saturday Weekend Argus, 15/16 April 1995: 15.

Silva, Penny (Managing Ed.). 1996. A Dictionary of South African English on Historical Principles. Cape Town: Oxford University Press.

Skuttnabb-Kangas, Tove and Robert Phillipson (Eds.). 1994. Linguistic Human Rights: Overcoming Linguistic Discrimination. Berlin / New York: Mouton de Gruyter.

Stubbs, M. 1986. Educational Linguistics. Oxford: Basil Blackwell.

Titlestad, Peter. 1996. English, the Constitution and South Africa's Language Future. De Klerk, Vivian (Ed.). 1996: 163-173.

Wilhelm, Peter. 1996. Gatvol with this Pointless Exercise. Letter. Sunday Times, 8 September 1996: 22. 